\title{
Evaluation of drying methods on some nutritional and volatile components of Bombay red onion (Allium cepal L.)
}

\author{
Ayalew Demissew ${ }^{1}$, Ayenew Meresa ${ }^{2}$ and Keber Temesgen ${ }^{3}$ \\ ayalewdemissew@yahoo.com \\ Amhara Regional Agricultural Research Institute \\ arari@ethionet.et \\ Bahir Dar Food Science and Postharvest Handling Research Center \\ P.o.box 794, Cell phone +251912604705
}

\begin{abstract}
Onion (Allium cepa L.) is a strong-flavoured vegetable consumed in different ways and its distinctive flavor or simply pungency. Onion has also important natural compounds effective for medical functions. Its importance is directly related with high content of high organosulphur compounds. Shelf life of fresh onion bulb is short enough due to the presence of high moisture content where postharvest loss of onion bulb reaches up to $50 \%$ in the production season. Consequentially Onion bulb had extreme variable market price during production and off season which affect both growers and consumers. So in this study the nutritional and volatile components of different drying methods of onion were evaluated. Effect of different drying method on protein, carbohydrate, total sugar, fat, pyurvic acid, ascorbic acid, total phenol, total flovonol, rehydration ratio, colour and sensory properties of onion slice were evaluated and found insignificant at $(\mathrm{P}<0.05)$ for microwave and modified direct solar dryer. But oven drying method had significant effect on onion bulb quality attributes at $(\mathrm{P}<0.05)$ than other two drying methods.
\end{abstract}

Key word: Onion, drying, bioactive, nutritional and organoleptic 


\section{Introduction}

Onion (Allium cepa L.), an incredibly used vegetable, ranking third from major vegetables produced in the world. Onion is a strong-flavored vegetable used in a wide variety of ways mainly for its distinctive flavor, aroma or simply pungency (Kumar,S., et.al, 2007). Some researcher also reported about its importance as a biological compound and medical functions. Such use is also directly related with their high content of organo-sulphur compounds (CorzoMartinez, M., et.al, 2007). Onion bulb is a perishable agricultural produce which limits economical growing of onion bulb (Endalew W, et.al, 2014). Evaluating and recommending long different preservation techniques is a solution to extend shelf life of onion bulbs so that it will be available in all seasons and localities to meet the demand during the whole year in all areas (Miedema, P., 1994). Processing and stabilizing of onion bulb have the advantage of both the growers and consumers (Ayalew D, et.al, 2017). In the production of processed commercial foods such as soups, sauces, sausage, and meat food products dried onion is basic ingredient used as flavouring agent. Dried onion products are sometimes preferred than fresh onion bulbs because of its simplicity of for use and greater shelf stability (Mazza G. and Lemaguer M., 1980). Drying of onion bulb is performed by applying heat energy on onion slice does not only remove moisture content, it also influence the nutrient and may distract volatile and bioactive component. Major drying methods of agricultural products are open air and hot air drying techniques. Open air drying methods mainly practiced in rural areas while hot air drying techniques mainly used in urban areas. Both drying method have their own merits and demerits on nutritional values, bioactive component loss, colour, shrinkage and other organoleptic properties of the agricultural produces (Mazza G and Lemaguer M., 1980). The domestic demand for energy substantially exceeds supply and on the contrary solar energy is an ideal way for drying of agricultural produces in sub-Saharan countries like Ethiopia. The supply of solar energy is abundant in almost all locations of the country. This concern have focused our attention to the potential of harnessing the opportunity to develop modified direct solar dryer and evaluation its efficiency by comparing with commercial dryers like oven and microwave dryers. Therefore in this study the effect of three drying methods was evaluated on physical, biochemical, nutritional and sensory quality attributes of onion flake and recommended the technology to the end user. 


\section{Materials and methods}

\section{Sample collection and preparation}

Bombay red onion sample was collected from Adet agriculture research center and trimmed to remove contaminated, injured and other extraneous materials. Then inedible part of the onion bulb was removed and sliced uniformly at slice thickness of $5 \mathrm{~mm}$. Finally sliced onion was dried up to a moisture content of $12 \%$ using three different drying methods (drying temperature of oven and microwave was adjusted at $50^{\circ} \mathrm{C}$ while the drying temperature of modified direct solar dryer was uncontrolled so it was simply measured using data logger). Selection criteria for drying temperature of oven and microwave dryer were literature based approach. Dried onion slice was packed in polyethylene bags and set further analysis of quality attributes.

\section{Proximate composition analysis}

Proximate composition: The proximate compositions such as moisture, crude fiber, total carbohydrate, ash and crude fat contents of onion were determined according to a method (AOAC, 1990).

\section{Bioactive component analysis}

Total phenol content: Onion sample total phenolic content was determined by Folin-Ciocalteu method as described by (Gao A. et.al. 2000). Distilled water of $0.44 \mathrm{ml}$ and $0.02 \mathrm{ml}$ of Folin reagent were added to $0.02 \mathrm{ml}$ of extract/suspension of the sample $(2 \mathrm{mg} / \mathrm{ml})$. After 3 minutes resting, $0.4 \mathrm{ml}$ of $20 \% \mathrm{Na}_{2} \mathrm{CO}_{3}$ was added. The mixture was vortexed and incubated for $20 \mathrm{~min}$ at $40^{\circ} \mathrm{C}$ using a water bath; thereafter the absorbance was read against a blank at $760 \mathrm{~nm}$ using a UV-spectrophotometer. The total phenolic content was determined using the standard curve $(\mathrm{y}=$ $0.022 \mathrm{x} ; \mathrm{r} 2=0.9945)$ obtained with Gallic acid. The contents were expressed as $\mathrm{mg}$ of Gallic Acid Equivalent/100g of the samples.

Ascorbic acid content: Ascorbic acid content of the fresh and dehydrated onion was determined using titration method by (Ranganna S., 1986). The reduction of 2, 6-dichlorophenol indophenol dye by ascorbic acid and expressed in mg per $100 \mathrm{~g}$. 
Total Flavonol content: Aluminum tri-chloride method, as described by (Padmaja M. et al. 2011) was used to determine the total flavonoid content onion samples. One hundred (100) $\mu \mathrm{L}$ of extract/suspension was mixed with $1.49 \mathrm{ml}$ of distilled water before introduction of $0.03 \mathrm{ml}$ of $5 \% \mathrm{NaNO}_{2}$. After $5 \mathrm{~min}$ resting, $0.03 \mathrm{ml}$ of $10 \% \mathrm{AlCl} 3$ was added and the mixture allowed to rest. After $6 \mathrm{~min}, 0.2 \mathrm{ml}$ of $1 \mathrm{M} \mathrm{NaOH}$ and $0.24 \mathrm{ml}$ distilled water were respectively added and the mixture was vortexed and the absorbance was measured at $510 \mathrm{~nm}$ using UVspectrophotometer. The flavonoid content was determined using the standard curve $(y=0.1972 \mathrm{x}$; $r^{2}=0.9972$ ) obtained with Catechin. The contents were expressed as $\mathrm{mg} \mathrm{CE} / \mathrm{g}$ of onion sample.

Pyruvic acid content: Pyruvic analysis was performed in triplicate according to the method of Abayomi et al. (1961) with slight modifications. Briefly, $10 \mathrm{~g}$ of chopped onion was homogenized for $3 \mathrm{~min}$ in $10 \mathrm{~mL}$ distilled water. The homogenate was centrifuged for $10 \mathrm{~min}$ at $20,000 \mathrm{rpm}$ and the supernatant was removed for pyruvate assay. Supernatant of $1.5 \mathrm{~mL}$ were then diluted 10-fold in de-ionized water. An aliquot of $0.5 \mathrm{~mL}$ was added to $1 \mathrm{~mL}$ of 2, 4dinitrophenyl hydrazine $(0.0125 \%$; v/v) in $2 \mathrm{~mol} / \mathrm{L} \mathrm{HCl}$ and $1.5 \mathrm{~mL}$ de-ionized water in a boiling tube. The reaction mixture was vortexed and kept for $10 \mathrm{~min}$ at $37^{\circ} \mathrm{C}$ temperature and after cooling $5 \mathrm{~mL}$ of $0.6 \mathrm{~mol} / \mathrm{L} \mathrm{NaOH}$ was added, and the absorbance was measured at $420 \mathrm{~nm}$ with Shimadzu UV-1700 spectrophotometer. The calibration curve was made by preparing pyruvic acid solutions at concentrations $0.04-0.4 \mathrm{mmol} / \mathrm{L}$ in water and the pyruvic acid concentration were expressed in terms of $(\mu \mathrm{mol} / \mathrm{g}$ fresh weight $(\mathrm{FW}))$.

Rehydration ratio: Rehydration ratios of dehydrated onion slice were determined by the methods suggested by (Ranganna S.1986). The rehydration characteristics of the dehydrated onion slice were studied in terms of the rehydration ratio.

Sensory analysis: A trained panel of 15 members evaluated the color, appearance, texture, flavour, taste and overall acceptability of the products on a nine-point hedonic scale. The panelists were unaware of the project objectives. Samples were coded with three-digit random numbers and then served. Panelists were provided with a glass of water, and were instructed to rinse and swallow water between samples. They were given written en instructions and asked to evaluate the overall acceptability of the products based on their appearance, texture, taste and color using a nine-point hedonic scale (1=dislike extremely to $9=$ like extremely) a method described by (Meilgaard M., et.al,1999). 


\section{Statistical analysis}

Data collected from the experiment were analyzed by statistical analysis such as descriptive statistics and analysis of variance (ANOVA).

\section{Result and discussion}

\section{Drying environment of direct solar dryer}

As it is observed in the figure-one below the maximum drying temperature of modified direct solar dryer was about $45^{\circ} \mathrm{C}$. Drying temperature and relative humidity of modified direct solar dryer was recorded by data logger.

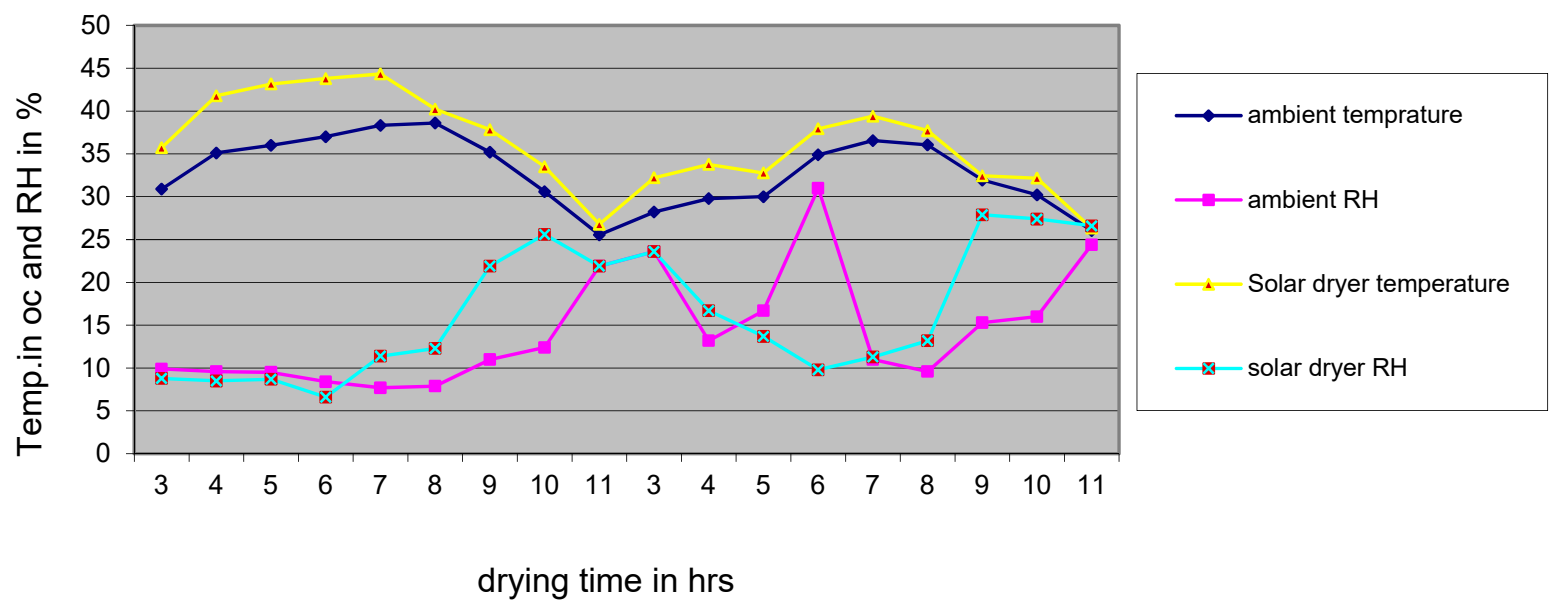

Figure-1: Drying temperature and relative humidity of modified direct solar dryer cabinet

\section{Proximate composition of fresh and dried onion}

The proximate compositions fresh and dried flake of onion samples were found as moisture (42.24\%), protein $(2.73 \%)$, carbohydrate $(77.35 \%)$, ash $(47.36 \%)$ and fat $(1.08 \%)$ as shown in table-one below. In this study the dry matter content of Bombay red onion was $63.76 \%$ in dry weight basis which is a big higher than other researcher's finding and report. In case of proximate composition different result was reported by (Kahane R., et.al, 2001). But similar result was reported by (Nweinuka,NM., et.al, 2005). Onion flake dried by three different drying methods (oven and microwave at $50^{\circ} \mathrm{c}$ and direct solar dryer) did not show significant difference 
$(\mathrm{P}<0.05)$ in terms of protein, carbohydrate and ash content. In investigating the effect of drying method on quality loss of onion by (Pramod G.et.al, 2014) similar result was reported. The proximate composition of onion slice in (dry weight basis) in this study coincides with finding and report by (Mitra J.et.al, 2011) at drying temperature of $35^{\circ} \mathrm{C}$.

Table-1: Fresh onion bulb and onion flake nutritional content /dry weight basis/

\begin{tabular}{llllc}
\hline Item & Protein [\%] & Carbohydrate [\%] & Ash [\%] & F at [\%] \\
\hline Fresh onion & $2.73 \pm 0.15$ & $12.35 \pm 0.01$ & $47.36 \pm 0.01$ & $1.08 \pm 0.02$ \\
SD onion flake & $2.70 \pm 0.15$ & $12.65 \pm 0.08$ & $47.12 \pm 0.08$ & $1.21 \pm 0.06$ \\
MW onion flake & $2.72 \pm 0.12$ & $12.71 \pm 0.05$ & $47.03 \pm 0.01$ & $1.02 \pm 0.02$ \\
OV onion flake & $2.69 \pm 0.13$ & $12.12 \pm 0.09$ & $47.12 \pm 0.08$ & $0.98 \pm 0.02$
\end{tabular}

*Values are mean \pm standard deviations of triplicate, $S D=$ Solar dryer, $M W=$ Microwave dryer and $O V=$ Oven dryer

\section{Bioactive component}

Total polyphenol: Polyphenols are well known to put on display as antioxidant activity all the way through a diversity of mechanisms, including free radical scavenging, lipid peroxidation and chelating of metal ions in addition to having many other biological activities, such as antihistamine as founded and reported by (Shahidi F.et.al, 1997). The major phenolics found in onion are quercetin, gallic acid, ferulic acid, and their glycosides (Nitta Y.et.al, 2007). Polyphenol content of fresh, microwave dried, oven dried and solar dried onion was found 185.65 (GAE)/100g, 185.35 (GAE)/100g 181.23/100g and 183.45/100g respectively as shown in table-2 below. Insignificant difference $(\mathrm{P}<0.05)$ was observed in polyphenol content of onion flake among drying methods. Similar effect of drying method on ployphenol content of onion was reported by (Mazza, G. and Le Maguer, M. 1979).

Pyruvic acid content: Pungency change of onion throughout drying of onion has been linked with high temperature breakage of pyruvic acid molecules. Pyruvic acid changed significantly at different drying temperature (Freeman, G.G. and N. Mossadeghi. 1970). Pyruvic acid is a trustworthy indicator of pungency. Pyruvic acid is unwavering product from the hydrolysis of Salk(en)yl-1-cysteinesulphoxide. When the onion cell is ruptured by cutting and chopping, the enzyme alliinase hydrolyse S-alk(en)yl-1-cysteinesulphoxide. Pungency of onion slice reduces significantly at $(\mathrm{p}<0.05)$ when dried at $70^{\circ} \mathrm{C}$ since most volatile compounds have low boiling 
point (Mazza, G., Le Maguer, M. 1979). Pyruvic a acid content decrease with the increase in drying temperature $65^{\circ} \mathrm{C}$. On the contrary with result there is also a finding for which high drying temperature had high pungency in the dried onion flake. It can also be explained that accelerated drying in the initial stages would retain this volatile compounds locked into the product when it reaches the critical moisture content. In this study Pyruvic acid concentration in fresh and dried onion flakes did not change significantly at $(\mathrm{p}<0.05)$. Pyruvic acid content for fresh, microwave dried, oven dried and solar dried onion samples were found $78.46 \mu \mathrm{mol} / \mathrm{g}$, $77.50 \mu \mathrm{mol} / \mathrm{g}, 72.56 \mu \mathrm{mol} / \mathrm{g}$ and $77.97 \mu \mathrm{mol} / \mathrm{g}$ respectively. Sulfur composition has been reported to strongly influence flavor in onion. Another contradicting report was found by (Randle, W.M. 1997) who stated that there was an increase of pyruvic acid with respect to the fresh sample during the drying at different temperatures. Pyruvic acid content in onion depends on several factors such as dry matter, sugar content, cultivars, maturity and sulphur nutrition. Several environmental factors have been identified, which can alter onion flavor.

Total flavonol content: Different flavonols have been identified and characterized. From these quercetin derivatives are the most significant ones in all onion varieties which are significantly reduced during drying (Griffiths, G.et.al, 2002). Total flavonol (quercetin and its glysosides) content of fresh onion and onion flake are given in table-two below and total flavonol for fresh, oven, microwave, and solar dried onion were $4.67 \mu \mathrm{mol} / \mathrm{g}, 4.31 \mu \mathrm{mol} / \mathrm{g}, 4.65 \mu \mathrm{mol} / \mathrm{g}$ and $4.56 \mu \mathrm{mol} / \mathrm{g}$ respectively. In this experimental result total flavonol content did not change significantly at $(\mathrm{p}<0.05)$ with different drying methods. Different result was reported by (Slimestad, R.et.al, 2007) in which flavonol content varied significantly at $(\mathrm{p}<0.05)$ along drying methods.

Ascorbic acid content: An increase in drying air temperature had a negative effect on quality ascorbic acid. This is due to the rupture down at high temperatures and the sensitivity of ascorbic acid to heat to oxidation humiliation. The ascorbic acid content of fresh, oven dried, microwave dried and solar dried onions were shown in table- 2 below and the values were $57.65 \mathrm{mg} / 100 \mathrm{~g}$, $57.43 \mathrm{mg} / 100 \mathrm{~g}, 61.45 \mathrm{mg} / 100 \mathrm{~g}$ and $58.55 \mathrm{mg} / 100 \mathrm{~g}$ respectively. The statistical analysis on the relationship between drying methods and ascorbic acid content did not show any significant correlation at $(\mathrm{p}<0.05)$. Other research results show loss of ascorbic acid content at significant difference in the dried sample (Nuutila, A.M. et.al, 2003). This is due to volatile nature of flavour components and also ascorbic acid is known as if it was temperature dependent. 
Table-2: Drying effect on bioactive and antioxidants onion

\begin{tabular}{|c|c|c|c|c|}
\hline Item & $\frac{\text { Total phenol }}{(\mathrm{GAE}) / 100 \mathrm{~g}}$ & $\frac{\text { ascorbic acid }}{\mathrm{mg} / 100 \mathrm{~g}}$ & $\frac{\text { pyruvic acid }}{\mu \mathrm{mol} / \mathrm{g}}$ & $\frac{\text { Total flavonol }}{\mathrm{mgCE} / \mathrm{g}}$ \\
\hline Fresh onion & $185.65 \pm 0.08$ & $57.65 \pm 0.37$ & $78.46 \pm 0.89$ & $4.67 \pm 1.23$ \\
\hline SD dried onion & $183.45 \pm 0.26$ & $58.55 \pm 1.02$ & $77.97 \pm 0.78$ & $4.56 \pm 0.48$ \\
\hline MW dried onion & $185.35 \pm 0.98$ & $61.45 \pm 0.87$ & $77.50 \pm 0.37$ & $4.65 \pm 1.09$ \\
\hline OV dried onion & $181.23 \pm 0.14$ & $57.43 \pm 0.87$ & $72.56 \pm 0.59$ & $4.31 \pm 0.98$ \\
\hline
\end{tabular}

*Values are mean \pm standard deviations of triplicate, $S D=$ solar dryer, $M W=$ microwave dryer and $O V=$ oven dryer

Sensory quality: Mean scores for aroma, flavour, taste, appearance, colour and overall acceptability shown in table thee below. In this study, sensory qualities of onion flake dried by different drying methods were investigated as compared to fresh onion and show no significant difference $(p<0.05$. The sensory scores of all the sensory attributes except taste did not vary significantly with the drying methods. Nearly similar result was observed that there was no significant variation in sensory scores of samples dried at 50,55 and $60^{\circ} \mathrm{C}$, but colour, varied significantly. Similar result reported as sensory quality of onion flake show insignificant difference at $(\mathrm{P}<0.05)$ as compared to fresh onion (Anju S. et.al, 2010). Onion flake dried for two days prepared using modified direct solar dryer was found acceptable by the panelists. The taste of onion flake had higher values than the fresh onion scores and this increment may be due to high concentration of total sugars in onion flake than the fresh onion (Achanta S.et.al, 2000).

Table-3: Onion organoleptic score results along drying time

\begin{tabular}{lcccc}
\hline Item & Fresh onion & MW dried onion & OV dried onion & SD dried onion \\
\hline Aroma & $8.9 \pm 0.90$ & $9.0 \pm 0.45$ & $9.0 \pm 0.88$ & $9.0 \pm 0.71$ \\
Flavour & $9.0 \pm 0.80$ & $8.5 \pm 0.56$ & $8.2 \pm 0.79$ & $8.9 \pm 0.61$ \\
Taste & $7.6 \pm 0.12$ & $7.8 \pm 0.79$ & $8.1 \pm 0.95$ & $8.3 \pm 0.34$ \\
Appearance & $9.0 \pm 0.96$ & $8.2 \pm 0.92$ & $8.4 \pm 0.86$ & $8.7 \pm 0.78$ \\
Colour & $8.7 \pm 0.68$ & $8.5 \pm 0.45$ & $8.6 \pm 0.23$ & $8.6 \pm 0.35$ \\
Overall acceptability & $8.5 \pm 0.78$ & $8.6 \pm 0.53$ & $8.6 \pm 0.18$ & $8.7 \pm 0.65$ \\
*Values are mean \pm standard deviations of 15 panelists, SD=solar dryer, MW=microwave dryer and OV=oven \\
dryer
\end{tabular}


Rehydration: The rehydration characteristics of a dried product are widely used as indicators of quality dried product. Rehydration is a complex process that is influenced by both physical and chemical changes associated with drying and the treatments preceding dehydration and reported rehydration ration of onion was 6.87 (Lewicki PP.et.al.1998). The result found in the experiment was nearly similar with the one reported previously. The rehydration quality parameter data of onion slice is given in table-4 below. The drying process causes changes in the permeability of the cell walls, loss of osmotic pressure and solute migration which affects the rehydration ratio. The rehydration ratio of onion slice ranges 7.87 to 5.65 along the drying methods. Each drying method had significance difference at $(\mathrm{p}<0.05)$ in rehydration ratio dried onion flake. The rehydration ratio of solar and microwave dried onion products show insignificance difference at $(\mathrm{p}<0.05)$. When rehydrating a dried product, it will never regain the same condition as before drying. The less elastic cell walls and the reduced water holding capacity of protein and starch, all decrease the rehydration ratio of the products but this phenomenon will be reduce significantly by optimizing drying process as it is in our finding. So, the negative factors regarding rehydration of the cells will be less than with a poor drying technique as stated (Kumar HSP.et.al, 2004).

Table-4: Quality parameter of onion slice along drying period

\begin{tabular}{lc}
\hline Item & Rehydration Ratio $[\mathrm{RR}]$ \\
\hline SD dried onion & $7.87 \pm 0.98^{\mathrm{ac}}$ \\
$\mathrm{MW}$ dried onion & $6.86 \pm 0.68^{\mathrm{bc}}$ \\
$\mathrm{OV}$ dried onion & $5.65 \pm 0.89 \mathrm{abc}$ \\
\hline *Values are mean \pm standard deviations, $S D=$ solar dryer, $M W=$ microwave dryer and OV=oven dryer and values \\
with different letter significantly different $(p<0.05)$.
\end{tabular}

\section{Conclusion}

It can be disclosed from this work that Bombay red onion in Ethiopia has better crude proteins, total carbohydrates, crude fat and bioactive components like ascorbic acid, pyruvic acid, falvonol and phenol content. The overall interpretation of this present investigation may offer a scientific basis for increased and versatile utilization of these carbohydrate-rich onions as a food component and carbohydrate supplement. In this study it appeared that modified direct solar 
drying method had more quality dried product than oven and microwave dried onion products. The quality parameters of dried onion were also influenced by the drying temperature and time. Drying environment of modified direct solar dryer was an appropriate technique of extending shelf life of onion with preserving its physical and chemical characteristics of fresh onion bulbs.

\section{Reference}

1. Achanta S, Okos MR. (2000). Quality changes during drying of food polymers. In Mujumdar, AS, Suvachittanont, S (eds).Development in drying, Vol. 2: food dehydration, Kasetsart University Press, pp. 195-209

2. Anju Sangwan, A. Kawatra and Salil Sehgal. (2010). Nutritional evaluation of onion powder dried using different drying methods, J. Dairying. Foods \& H.S., 29 (2): 151 - 153.

3. Ayalew D, Ayenew M, Mehiret M. (2017). Testing and Demonstration of Onion Flake Processing Technology in Fogera Area at Rib and Megech River Project. J Food Process Technol 8: 677. doi: 10.4172/2157-7110.1000677.

4. Corzo-Martinez, M., N. Corzo and M. Villamiel. (2007). Biological properties of onions and garlic. Trends in Food Science \& Technology, 18: 609-625.

5. Endalew, W., A. Getahun, A. Demissew, and T. Ambaye. (2014). Storage performance of naturally ventilated structure for bulb onion. Agric Eng Int: CIGR Journal, 16(3): 97-101.

6. Freeman, G.G. and N. Mossadeghi. (1970). Effect of sulphate nutrition on flavor components of onion (Allium cepa). J. Sci. Food Agr. 21:610-615.

7. Griffiths, G., Trueman, L., Crowther, T., Thomas, B., \& Smith, B. (2002). Onions - A global benefit to health. Phytotherapy Research, 16,603-615.

8. Kahane, R., Vialle-Guerin, E., Boukema, I., Tzanoudakis, D., Bellamy, C., Chamaux, C., Kik, C. (2001). Changes innon-structural carbohydrate composition during bulbing in sweet and highsolid onions in field experiments.Environmental and Experimental Botany 45, 73-83. 
9. Kumar HSP, Nagaraju PK, Radhakrishna K, Bawa AS. (2004). Effect of dehydration techniques on the quality of onion slices. J Food Sci Tech.; 41:397-400.

10. Kumar, S., Imtiyaz, M., Kumar, A. (2007). Effect of differential soil moisture and nutrient regimes on postharvest attributes of onion (Allium cepa L.). Scientia Horticulturae, 112, 121 129.

11. Lewicki PP, Lazuka WP, Rajchert DW, Nowak D. (1998). Effect of mode of drying on storage stability of coloured dried onion. Pol J Food Nutr Sci. 7:701-6.

12. Mazza G., Lemaguer M. (1980). Dehydration of onion: some theoretical and practical considerations. International Journal of Food Science \& Technology, 15: 181-194

13. Mazza, G. and Le Maguer, M. (1979). Volatiles retention during the dehydration of onion (Allium cpa L.), lwt, (12),333-337.

14. Miedema, P. (1994). Bulb dormancy in onion. The effects of temperatures and cultivar on different onion cultivars. Journal of Horticultural Science, 69, 29-39.

15. Mitra, J., Shrivastava, S.L. and Srinivasa Rao,P. (2011). Onion dehydration: a review. Journal of Food Science Technology, DOI 10.1007/s13197-011-1369.

16.Nitta Y, Kikuzaki H, Ueno H. (2007). Food components inhibiting recombinant human histidine decarboxylase activity. Journal of Agriculture and Food Chemistry 55, 299-304.

17. Nweinuka,NM; Ibeh, G O; Ekeke, G.I. (2005). Proximate Composition And Levels Of Some Toxicants In Four Commonly Consumed Spices J. Appl. Sci. Environ. Mgt.Vol.9(1) 150-155.

18. Nuutila, A.M., Puupponen-Pimia, R., Aarni, M., Oksman-Caldentey, K.M. (2003). Comparison of antioxidant activity of onion and garlic extracts by inhibition of lipid peroxidation and radical scavenging activity. Food Chemistry, 81(4): 485-493.

19. Pramod G., Ramachandra C., Nidoni U. (2014). Dehydration of Onions with Different Drying Methods 3(3),210-216.

20. Randle, W.M. (1997). Onion Flavor Chemistry and Factors Influencing Flavor Intensity, p.41-52. In: S.J. Risch and C.T. Ho (eds.). Spices Flavor Chemistry and Antioxidant Properties. Amer. Chem. Soc., Washington, DC. 
21. Shahidi F, Amarowicz R, He YH, Wettasinghe M. (1997). Antioxidant activity of phenolic extracts of evening primrose (Oenothera biennis): A preliminary study. Journal of Food Lipids 4, 75-86.

22. Slimestad, R., Fossen, T. \& Vagen, I.M. (2007). Onions: a source of unique dietary flavonoids. Journal of Agricultural and Food Chemistry, 55, 10067-10080. 